\title{
The Effect Of Core Training On Some Motoric Features Of University Footballers
}

\author{
Yakup Akif Afyon \\ Correspondence: Yakup Akif Afyon, Faculty of Spor Sciences, Sitki Kocman University Assoc. Prof. Muğla. Turkey.
}

Received: December 18, 2018

Accepted: January 20, 2019 Online Published: February 13, 2019

doi:10.11114/jets.v7i3.3885

URL: https://doi.org/10.11114/jets.v7i3.3885

\begin{abstract}
In this study, the effect of core training on some motor features of university footballers has been examined. 36 footballers both studying at Muğla Sitkı Koçman University in Muğla, Turkey and playing in amateur leagues participated in the study. 18 university footballers of Muğla Sitkı Koçman University Sports Club who play in Muğla Super Amateur League formed the experimental group (EG) (Age $X=21.4 \pm 2.12$ years, Height $X=174.3 \pm 6.84 \mathrm{~cm}$ and Weight $\mathrm{X}=75.9 \pm 8,43 \mathrm{~kg}$ ). 18 footballers with amateur licences who play in the Faculty of Economics and Adiministrative Sciences, train regularly and play in the university faculty matches formed the control group (CG) (Age $X=21,6 \pm 2.56$ years, Height $X=176.7 \pm 7.13 \mathrm{~cm}$ and Weight $X=76.3 \pm 8.43 \mathrm{~kg}$ ). The required permissions were obtained and the students filled in the "Admission Consent Forms" before the applications. The trainings were done in the football field of Muğla Sitk1 Koçman University and the measurements were taken in the Faculty of Sports Sciences Physiology Laboratory. The 10-movements core training programme for eight weeks was applied to the EG footballers in addition to their weekly 2-day football training when the footballers in the CG continued their regular trainings.

Before the study, the leg strength, back strength, right-left hand griping strength, flexibility, and vertical jump measurement were taken as pre-test values. After the 8-week training, the final measurements of the EG and the CG were taken. The comparison between the Pretest and Posttest was studied statistically with paired sample $t$ test at 0.05 significance level

Consequently it was determined the that the 8-week Core Training provided the undergradute footballers with an improvement of their the leg strength, back strength, right hand griping strength and vertical jump $(\mathrm{p}<0.05)$. No improvement in flexibility features was observed.
\end{abstract}

Keywords: football training, strength, core, motor features, university students

\section{Introduction}

The most popular sport in the world, football is a complex discipline using aerobic and anaerobic energy systems (Çetinkaya, et al., 2018). Football requires that motor and coordinative features such as high-level performance, force, endurance, speed, agility, balance and flexibility have been improved (Tanır, 2018). With its high intensity, intermittent presses, endurance, quick sprints, ball skills and coordination football is a sport that includes stable decision making and balance (Agostini, 1994). When the dimensions of the movement in football are examined, it is seen that it includes all dimensions of the sporty movement, such as strength, speed, strength, flexibility and coordination. Moreover, during a match, the player faces with the pressure of his opponent and the time pressure while performing his move. Therefore, training conditions and methods should be prepared by considering these facts (Başer, 1996). It is difficult to make a complete definition of the force, which includes both physical and spiritual perspectives. The reason for this is that, contrary to the physical definition of force; its other structural features such as muscle operation, muscle contraction or different forms of muscle contraction is versatile and it shows a complex feature depending upon being affected by various factors (Tamer, 2000).

For football training; It can be first and foremost said that the strength training methods are not only related to the number of training units performed during a football training about which strength method is appropriate (Wieneck, 2011). In addition, it has shown that a strength training associated with the game gives effective development stimuli in various practices and in other words it has also shown that force or quick force can easily be increased in integration (Cabri, et al. 1988; Togari, et al. 1988; De Proft, et al. 1988). The lower the level of efficiency or the level of training, the easier the force development, the more the increase in productivity can be provided with so simple means. At a very 
low efficiency level; the various force stimuli formed only by playing football are sufficient. However, on the other hand it must be accepted as an obligation that working with various methods and with more effective methods even if the ability for efficiency or the level of training are so high (Weineck, 2011).

Core concepts in the field of sport science has been identified as an important component for "functional athletic performance" (Hibbs et al, 2008; Dendas, 2010). Core can be defined as a part of body providing adequate support for lower and upper extremity movements during an athletic performance (Dendas, 2010). In other words, the core concept can have described as the combination of muscle groups "forming the body, supporting and surrounding the spine", having an active role in the integrity of the muscle groups in the upper and lower limb power switches" (Boyac1 et al., 2018). It is seen that strengthening the core muscles is an important factor for avoiding sport injuries and speeding up the returns to the field for rehabilitation along with improving the physical performance. Therefore, core training has recently become a widely used method for strength development.

Football is a sports branch with a lot of struggle. Soccer players practicing strength are more powerful in tackles. There are many practices developing strength. Strongness of the central region will primarily reduce the risk of injuries. The explosive force in football has a significant and a high anaerobic energy potential. The common training methods are not enough for the development of anaerobic power in football, vertical leap, speed and acceleration ability, quickness and agility, ball kick and drilling. Therefore, core training will provide some benefits not only for the development of some physiological and motoric features of footballers considering their upper level training and success but also for time and money. The aim of this study is to examine the effects of 8-week core training and some motoric features of university footballers.

\section{Method}

\subsection{Participants}

In the research, experimental method with pretest- posttest pattern was used. 36 footballers playing in Mugla province in Muğla at amateur participated in the study voluntarily. Core training $(\mathrm{n}=18)$ and control $(\mathrm{n}=18)$ groups were formed in the study. Before the tests, the permissions had been obtained from the sportsmen's' clubs and faculties. It was confimed that they had nothing preventig them to train and the measures were taken in accordance with International Helsinki convention.

\subsubsection{Experimental Group (EG)}

It was formed with licensed footballers of Muğla University Sports Club in Super Amateur Group who play in Amateur League matches in Muğla. Sportsman participated in twice weekly Core Training, which lasted 8 weeks.

\subsubsection{Control Group (KG)}

It was formed with footballers playing in Muğla University League, practicing regularly, studying in the Faculty of Economics and Administrative Sciences football team playing in the amateur matches at the weekend. The athletes continued their football training for 8 weeks and did not have any additional practice.

\subsection{Obtaining Data and Measurement Tools Used}

The height, weight, vertical jump, flexibility and strength measurements of the groups were taken by researcher at the Physiology Laboratory of Muğla Sitkı Koçman University.

\subsubsection{Flexibility Measurement}

Sit and reach test was used. The longest distance stretched by the ruler on the resilience stand is considered the flexibility value. The best of the two applications without knees are recorded (Tamer, 2000).

\subsubsection{Vertical Jumps Measurement}

It was taken using the Vertical Jump Test (Jump Meter). Sportsmen jumped up with all teir strenghts on the precision ground with distance measurement tool without stepping or hopping and the measurement was taken in centimeter. After the sportsmen had jumped twice, the best degree was recorded as the vertical jump value. The movements should be performed maximum effort and the rest should be complete (Tamer, 2000).

\subsubsection{Hand, Leg and Back Strentgh Measurement}

For the best result hand grip strengths are recorded standing with Takei brand hand dynamometer by means of left and right hand contractions. The arm makes a 45 degrees angle with the body and measurements are taken four times (hand grip) with left and right hand with static contractions 45' angle of the arm body is taken four times each time the best results are recorded. Sportsmen step up on the Takei brand the machine working according to pressure principle the leg and pulls the chain to the working tool according to the Takei brand pressure principle and they pull the chain with the 
knees bent, facing the ahead, applying maximum strentgh at the level of knees. The best of four measurement recorded in kilogram as the back and leg strength (Tamer, 2000).

\subsection{Training Program}

10-movements core training programmes improving the core region have been prepared by reviewing the literature and taking expert opinions. The studies were carried out for 8 weeks and twice a week in addition to the regular training in the olympic grass field. The Core Training programme was carried out by two research assisstants working in Mugla Sitk1 Koçman University Faculty Sport Sciences and general and specific warm-up exercise suitable for the moves in the training were done for 15-20 minutes by the footballer before the training.

Table 1. 8-Weeks Core Training Program Implemented

\begin{tabular}{|c|c|c|c|c|}
\hline EXERCISES & 1-2. Week & 3-4. Week & 5-6. Week & 7-8. Week \\
\hline Movements & time / repeat & time / repeat & time / repeat & time / repeat \\
\hline 1. Side Bend & $20 \mathrm{sec}$ & $15 \mathrm{sec}$ & $12 \mathrm{sec}$ & $15 \mathrm{sec}$ \\
\hline 2. Power Shiver & $20 \mathrm{sec}$ & $15 \mathrm{sec}$ & $12 \mathrm{sec}$ & $15 \mathrm{sec}$ \\
\hline 3. Alternate Legs Jump & 15 & 10 & 8 & 10 \\
\hline 4. Squat & 15 & 10 & 8 & 10 \\
\hline 5. Chunch & 15 & 10 & 8 & 10 \\
\hline 6. Lying Twist Trunk & 15 & 10 & 8 & 10 \\
\hline 7. $\quad$ Twist With Medicine Ball & 15 & 10 & 8 & 10 \\
\hline 8. Side Bridge & $20 \mathrm{sec}$ & $15 \mathrm{sec}$ & $12 \mathrm{sec}$ & $15 \mathrm{sec}$ \\
\hline 9. Alternate Plank & $20 \mathrm{sec}$ & $15 \mathrm{sec}$ & $12 \mathrm{sec}$ & $15 \mathrm{sec}$ \\
\hline 10. Alternate Superman & 20 & 10 & 8 & 10 \\
\hline
\end{tabular}

Core Training program; was applied in accordance with the principles of the wave loading and the participants had rests considering loading duration and repetition (1-2. Week 1 Set, 3-4. Week 2 Set, 5-6. Week 3 Set, 7-8. Week 2 Set).

\subsection{Statistical Analysis of The Data}

The data obtained were collected in SPSS for Windows 22.0 package program; the paired samples were analyzed using the t-test (Paired-Samples t-test) for the differences between the pretest-posttest of the experimental and the control groups. As the pre-test values of the experimental group; leg force, back force, right-left hand grip strength, flexibility and vertical jump measurements were obtained. Post-test measurements were taken after the 8-week of training.

\section{Findings}

The average age, height and weight of the experimental (EG) and control (CG) group players are given below.

Table 2. Descriptive statistics of groups

\begin{tabular}{|c|c|c|c|c|c|}
\hline \multirow[b]{2}{*}{$\begin{array}{l}\text { Characteristics } \\
\text { football players }\end{array}$} & \multicolumn{2}{|c|}{ Core training group $(\mathrm{EG})(\mathrm{n}=18)$} & \multicolumn{2}{|c|}{ CG $(n=18)$} & \multirow[b]{2}{*}{$p$} \\
\hline & $\begin{array}{l}\text { Avarage } \\
\text { (X) }\end{array}$ & $\begin{array}{l}\text { St. Deviation } \\
\text { (ss) }\end{array}$ & $\begin{array}{l}\text { Avarage } \\
(\mathbf{X})\end{array}$ & $\begin{array}{l}\text { St. Deviation } \\
\text { (ss) }\end{array}$ & \\
\hline Age (year) & 21,4 & $\pm 2,12$ & 21,6 & $\pm 2,56$ & ,864 \\
\hline Height $(\mathrm{cm})$ & 174,3 & $\pm 6,84$ & 176,7 & $\pm 7,13$ & ,783 \\
\hline Weight (kg) & 75,9 & $\pm 8,43$ & 76,3 & $\pm 7,15$ & 852 \\
\hline
\end{tabular}

$\mathrm{P}<0.05^{*}$

The averages of the groups has shown in Table 2 (EG ages 21,4 $\pm 2,12$ years, height 174,3 $\pm 6,84 \mathrm{~cm}$, weight 75,9 \pm $8,43 \mathrm{~kg}$, CG ages $21,6 \pm 2,56$ years, height $176.7 \pm 7.13 \mathrm{~cm}$, weight $(\mathrm{kg}) 76.3 \pm 8.43)$. There was no significant difference between the characteristics of EG and CG ( $p>0.05)$. 
Table 3. Comparison of pre-test averages of EG and CG with paired samples t-test

\begin{tabular}{lllll}
\hline Variables & EG pre test & CG post test & \multicolumn{2}{l}{ p } \\
\cline { 2 - 5 } & $\mathbf{X} \pm \mathbf{S S}$ & $\mathbf{X} \pm \mathbf{S S}$ & $\mathbf{t}$ &, 083 \\
\hline Leg Force (kg) & $112,24 \pm 23,50$ & $99,63 \pm 13,34$ & 1,844 &, 213 \\
\hline Back Strength (kg) & $123,45 \pm 30,31$ & $122,44 \pm 18,28$ & 1,293 &, 347 \\
\hline Right Hand Grip (kg) & $41,63 \pm 4,01$ & $40,07 \pm 5,02$ &, 968 &, 316 \\
\hline Left Hand Grip (kg) & $41,07 \pm 6,50$ & $38,96 \pm 5,77$ & 1,033 &, 189 \\
\hline Flexibility $(\mathbf{c m})$ & $33,02 \pm 8,17$ & $29,38 \pm 9,95$ & 1,370 &, 203 \\
\hline Vertical Jump $(\mathbf{c m})$ & $46,55 \pm 4,10$ & $45,05 \pm 2,73$ & 1,324 & \\
\hline
\end{tabular}

$\mathrm{P}<0.05^{*}$

There was no statistically significant difference in the EG and CG pre-tests ( $p>0.05$ ).

Table 4. The paired samples t-test analysis of the changes in the pre-test and post-test variables of the CG

\begin{tabular}{lllll}
\hline Variables & CG pre test & CG post test & & \\
\cline { 2 - 5 } & $\mathbf{X} \pm \mathbf{S S}$ & $\mathbf{X} \pm$ SS & $\mathbf{t}$ & $\mathbf{p}$ \\
\hline Leg Force (kg) & $99,63 \pm 13,34$ & $103,74 \pm 13,59$ & $-4,227$ &, $001^{*}$ \\
\hline Back Strength (kg) & $112,44 \pm 18,28$ & $114,76 \pm 17,87$ & $-2,926$ &, $009^{*}$ \\
\hline Right Hand Grip (kg) & $40,07 \pm 5,02$ & $41,74 \pm 4,89$ & $-6,740$ &, $000^{*}$ \\
\hline Left Hand Grip (kg) & $38,96 \pm 5,77$ & $40,07 \pm 5,91$ & $-4,788$ &, $000^{*}$ \\
\hline Flexibility (cm) & $29,38 \pm 9,59$ & $30,11 \pm 9,59$ & $-1,365$ &, 190 \\
\hline Vertical Jump $(\mathbf{c m})$ & $45,05 \pm 2,73$ & $47,33 \pm 3,14$ & $-8,997$ &, $000^{*}$ \\
\hline
\end{tabular}

$\mathrm{P}<0.05^{*}$

When the posttest results of the participants of experimental group after training are compered compared with posttest results of the participants of the control group who train normally we can say that the leg strength and the back strength have differed significantly $(\mathrm{p}<0.05)$. There were no significant differences in the results of flexibility values. It can be thought that this results show stretching is not enough.

Table 5. Analysis of changes in pre-test and post-test averages after EG by paired samples t-test

\begin{tabular}{lllll}
\hline Variables & EG pre test & EG post test & \multicolumn{2}{l}{ p } \\
\cline { 2 - 5 } & $\mathbf{X} \pm$ SS & $\mathbf{X} \pm$ SS & $\mathbf{t}$ &, $000^{*}$ \\
\hline Leg Force (kg) & $112,24 \pm 23,50$ & $128,11 \pm 28,21$ & $-6,14$ &, $000^{*}$ \\
\hline Back Strength (kg) & $123,45 \pm 30,31$ & $140,67 \pm 35,14$ & $-4,71$ &, $004^{*}$ \\
\hline Right Hand Grip (kg) & $41,67 \pm 4,01$ & $43,69 \pm 4,30$ & $-3,29$ &, 060 \\
\hline Left Hand Grip (kg) & $41,07 \pm 6,50$ & $42,58 \pm 5,42$ & $-2,01$ &, 626 \\
\hline Flexibility (cm) & $33,02 \pm 8,17$ & $33,75 \pm 6,25$ &,- 497 &, $000^{*}$ \\
\hline Vertical Jump (cm) & $46,55 \pm 4,10$ & $49,05 \pm 3,93$ & $-6,55$ &
\end{tabular}

$\mathrm{P}<0.05^{*}$

After the 8-week core training statistically significant differences were found in leg strenght, back strength, right hand grip strength and vertical jumps ( $\mathrm{p}<0.05$ ). Core training is known to be a study for the central region. The increase in leg and back area within the central region is an expected result. It can be thought that the reason of not developing the left hand grip strength is that their dominant hands are their right hands and that they can develop in their daily lives. However, the results of flexibility values did not improve contrary to the expectations. It is thought that this is due to the fact that the players do not have enough stretching moves. 
Table 6. EG posttest-CG posttest variables with the paired t-test analysis of changes seen.

\begin{tabular}{lllll}
\hline Variables & EG post test & CG post test & & \\
\cline { 2 - 5 } & $\mathbf{X} \pm \mathbf{S S}$ & $\mathbf{X} \pm \mathbf{S S}$ & $\mathbf{t}$ & $\mathbf{p}$ \\
\hline Leg Force (kg) & $128,11 \pm 28,21$ & $103,74 \pm 13,59$ & 3,009 &, $008^{*}$ \\
\hline Back Strength (kg) & $140,67 \pm 35,14$ & $114,76 \pm 17,87$ & 2,548 &, $021^{*}$ \\
\hline Right Hand Grip (kg) & $43,69 \pm 4,30$ & $41,97 \pm 5,10$ & 1,201 &, 246 \\
\hline Left Hand Grip (kg) & $42,58 \pm 5,42$ & $40,07 \pm 5,91$ & 1,278 &, 219 \\
\hline Flexibility (cm) & $33,75 \pm 6,25$ & $30,11 \pm 9,59$ & 1,458 &, 163 \\
\hline Vertical Splash (cm) & $49,05 \pm 3,93$ & $47,3 \pm 3,14$ & 1,485 &, 156 \\
\hline$p<0.05$ & & & &
\end{tabular}

When we compared the post-tests of the 8-week core training applied to the EG and the post-test of the CG performing normal football training; We can say that the leg and back strentghs within the central region gain meaningful differences with core training ( $\mathrm{p}<0.05)$. This may be due to the strengthening of the core region within the core training movements.

\section{Discussion and Conclusion}

In the study, footballers' 8 -week core training pre-test and post-test; posttest and pretest results were found to be; 112,24 $\pm 23,50$ posttest $128,11 \pm 28,21$, back force pretest $123,45 \pm 30,31$ posttest $140,67 \pm 35,14$, right hand grip pretest 41,67 $\pm 4,01$ posttest $43,69 \pm 4,30$, left hand grip pre-test $41,07 \pm 6,50$ post-test $42,58 \pm 5,42$, flexibility pre-test $33,02 \pm 8,17$ post-test $33,75 \pm 6,25$, vertical jump pre-test $46,55 \pm 4,10$ posttest $=49.05 \pm 3.93$. There were statistically significant differences between the legs, back and right hand gripping strength and vertical jumps $(\mathrm{p}<0.05)$. The reason for the lack of left hand gripping strength; it can be said that the right hands are dominant and they actively use their right hands in everyday life (the right hands of all experimental group players are dominant). Despite the expectations of a significant difference in flexibility values, no statistically significant difference was found. This may be due to the fact that the players do not perform the necessary stretching moves before, during and after the training. It can be said that core training is important as a strength training method in order to increase the struggling power of football players. When the literature is examined;

Leetun et al. (2004), said that core training had a positive effect on lower extremity injuries. Considering the very common lower extremity injuries in football in a group of 41 sportsmen including 28 males, 13 females. It can be thought that the core effect of the core training in our study, especially leg strength, can prevent lower extremity disability risks in football players.

Samson and Sandrey (2007), said that tennis is a branch of sport that includes mobility of the upper and lower extremity. They thought that the central areas of the female athletes who played tennis were strong. Our 8-week core training programme on footballers improved the core region and increased the leg and back strenghts and the vertical jump strengths of the players. Considering the benefits, it is parallel with our work.

In the study Hibbs et al. (2008), questioned whether the core training programme is for "improving the performance or reducing disability risks" they questioned that they were an exercise program. They said that core training programmes with different applications, could improve performance and minimize the disability risks. In our study, there is a positive increase in football players' strengths. These findings support the findings of our study.

Bassett and Llyod (2011) stated that elite gymnastics have improved their strength performance, plank positions and core areas as a result of the core training.

Sharrock et al. (2011) found that core training has a positive effect on athletic performance. The findings of the study are similar to our study.

Afyon and Boyaci (2013) reported significant differences in the motor parameters of the participants as a result of the core-pliometric training on sedantery. These results are in parallel with our study.

Santana (2005) found that the core training increase the male swimmers' strength. In our study, there was an increase in the force parameters of the core training so they are parallel.

Atici and Afyon, (2016) reported that there was a significant increase in the abilities of the sedentary female swimmers such as left hand grip, leg and back strength and flexibility 8-week Core training programme. These findings support our study. 
$\mathrm{Li}$ (2014), has found a positive impact on the motor training of the core training in athletes who have chosen a football course at the Civil Air School. It is in parallel with our study.

Afyon, (2014) 16-year-old footballer's vertical jump performances showed statistically significiant differences after 12 weeks of Core training programme $(\mathrm{p}<0.05)$. The findings are in parallel with our study.

Boyac1 and Afyon (2017) reported that there was a significant improvement in the athletic performance of the child footballers after 12 -week core training programme. The core training programme implemented in our study also improved the athletic performance (strength, anaerobic power) of the footballers. These results and some studies in the literature are parallel.

Boyac1 et al. (2018), in their research on the effect of dynamic and static core training on athletic performance of footballer children, 8-week core training has determined that they improve physical performance. In parallel with the results of the study, it was observed that there were significant differences in the motor parameters after core training applied to football players.

Boyac1 and Tutar (2018), in their study on footballer children, reported that 8-week Quad-Core training method improved the core strength and durability of child athletes. The results of this study are similar.

Thomas and William (2009), indicated that in the study carried out with women footballers in the First League The Core is not related to strength and performance. This result is not in parallel with our study and other studies. In our study, we see that the Core contributes positively to the development of force. It is thought that it is not parallel with our results due to gender differences and scope of training.

Jim et al. (2013), dermined that there was an improvement in a lot of parameters as a result of core and endurance trainings in the atudy on undergraduates. However, they did not find significant differences in vertical jump measurements. In the study we did with infrastructure footballers, significant differences were observed in vertical jumps. This differs from our study.

Mendes (2016), reported in his study on athletes license who play football in local football teams and school teams that the core training improved their physical performance. These results are similar with the results of our study.

As a result, it is seen that the core training which is applied for 8 weeks on the university footballers of the has a positive development in the leg strength, back strength, right-left hand grip strength and vertical jumps which are important for football (explosive force). When the studies in the literature are examined, the effect of core exercises on the central region and leg forces of children in developmental age is remarkable. It can be said that core training can contribute positively to the strength when applied in short term football training. More comprehensive studies are needed for determining the effect of the core trainings on sportsmen who play football in different leagues, and who are at different ages and of different genders.

\section{References}

Afyon, Y. A. (2014). Effect of core training on 16 year-old soccer players, Educational Research and Reviews, 9(23), DOI:10,5897/ERR 2014. 1876, 10 December, 2014 (ISSN 1990-3839), Pp. 1275-1279, Lagos / Nigeria.

Afyon, Y. A., \& Boyaci, A. (2013). Investigation of the effects by compositely edited core-plyometric exercises in sedentary man on some physical and motoric parameters. International Journal of Academic Research Part A; 5(3), 256-261. https://doi.org/10.7813/2075-4124.2013/5-3/A.37

Agostini, R. (1994). Medical and orthopedic issues of active and athetic women. Hanley \& Belfus Inc, Philadelphia.

Atici, M., \& Afyon, Y. A. (2016). The effects of core training on swimming in sedentary women anthropologist, (ISSN:0972-0073), 23(3), 542-549.

Bassett, S. H., \& Llyod, L. L. (2011). The effect of an eight-week training programme on core stability in junior female elite gymnasts. African Journal for Physical, Health Education, Recreation and Dance (AJPHERD), 17, suppI (Supplement), 9-19.

Başer, E. (1996). Futbolda Psikoloji ve Başarl, Sporsal Kuram Dizisi. 4, 2. bask1, Ankara.

Boyac1, A., \& Afyon, Y. A. (2017). The effect of the core training to physical performances in children. Journal of Education and Practice, 8(33), 81-88.

Boyac1, A., \& Tutar, M. (2018). The effect of the quad-core training on core muscle strength and endurance, International Journal of Sports Science, 8(2), 50-54.

Boyac1, A., Tutar, M., \& Biyıkl1, T. (2018). The effect of dynamic and static core exercises on physical performans in children. European Journal of Physical Education and Sport Science, 4(7), 50-61. 
Cabrid, J., DeProft, E., Dufour, W., \& Clarys, J. P. (1988). The relation between muscular strength and kick performance. In: Science and football, Spon, London-New York. 190.

Çetinkaya, E., Tanır, H., \& Çelebi, B. (2018). Comparison of agility, sprint, anaerobic power and aerobic capacities of soccer players by playing positions. Journal of Education and Training Studies, 6(9), 184-190. https://doi.org/10.11114/jets.v6i9.3560

De Proft, E., Cabrid, J., Dufour, W., \& Clarys, J. P. (1988). Training and kick performance in soccer players. In: Science and football, Spon, London-New York. pp. 112.

Dendas A. (2010). The relationship between core stability and athletic performance. [master's thesis]. Arcata, CA: Humboldt State University.

Hibbs, A. E., Thompson, K. G., French, D., Wrigley, A., \& Spears, I. (2008). Acte Data Intormation BV, All rights reserved, 38(12), 995-1008.

Jim, F. S., Jeff, C. M., John, R. B., \& Jacob, L. T. (2013). Effect of core strength and endurance training on performance in college students: randomized pilot study. Department of Exercise, Health, and Sport Sciences, 17, 278-290.

Leetun, D. T, Ireland, M. L., Willson, J. D., Ballantyne, B. T., \& Davis, I. M. (2004). Core stability measures as risk factors for lower extermity injury in athletes. American College of Sports Medicine, 0195-9131/04/3606-0926. 926-934

Li, H. (2014). Experimental research of applying the core strength training to the football elective course teaching in civil aviation universities, Journal of Chemical and Pharmaceutical Research, 6(1), 52-56. ISSN: 0975-7384.

Mendeş, B. (2016). The effects of core training applied to footballers on anaerobic power, speed and agility performance, Kamla-Raj Anthropologist, 23(3), 361-366. https://doi.org/10.1080/09720073.2014.11891956

Samson, K. M., \& Sandrey, M. A. (2007). A Core Stabilization Training Program For Tennis Athletes. Human Kinetics - ATT IZ(3), 41-46.

Santana, J. C. (2005). Strength training for swimmers: training the core. Strength and Conditioning Journal Volume $27(2), 40-42$.

Sharrock, C., Cropper, J., Mostad, J., Johnson, M., \& Malone, T. (2011). A pilot study of core stability and athletic performance: is there a relationship?. The International Journal of Sports Physical Therapy, 6, 63.

Tamer, K. (2000). Sporda Fiziksel-Fizyolojik Performansın Ölçülmesi ve Değerlendirilmesi, Bağırgan yayınevi, Sporsal Kuram Dizisi, Ankara.

Tanır, H. (2018). The effect of balance and stability workouts on the development of static and dynamic balance in 10-12-year-old soccer players. Journal of Education and Training Studies, 6(9), 132-135. https://doi.org/10.11114/jets.v6i9.3499

Thomas, W. N., \& William L.L. (2009). The relationship between core strength and performance in division I female soccer players. Official Research Journal of the American Society of Exercise Physiologists, 12(2), 21-28.

Togari, H., Ohashi, J., \& Ohgushi, T. (1988). Isokinetic Muscle Strength of Soccer Players. In: Science and football, Spon, London-New York. 183.

Weineck. J. (2011). Futbolda Kondisyon Antrenmanı. (Çev: T. Bağırgan). Spor Yayın evi ve Kitap evi. Spor kuramı dizi:5. Ankara. 194-195.

\section{Copyrights}

Copyright for this article is retained by the author(s), with first publication rights granted to the journal.

This is an open-access article distributed under the terms and conditions of the Creative Commons Attribution license which permits unrestricted use, distribution, and reproduction in any medium, provided the original work is properly cited. 